\title{
Entomofauna associated to fruits and seeds of two species of Enterolobium Mart. (Leguminosae): Harm or benefit?
}

\author{
Marcos Vinicius Meiado ${ }^{1}$, Eliana Akie Simabukuro² \& Luciana Iannuzzi ${ }^{3}$
}

\begin{abstract}
${ }^{1}$ Laboratório de Sementes, Centro de Referência para Recuperação de Áreas Degradadas, Universidade Federal do Vale do São Francisco, Campus de Ciências Agrárias, BR 407, Km 12, Lote 543, S/N, C1, Projeto de Irrigação Nilo Coelho, Caixa Postal 252, 56300-990 Petrolina-PE, Brazil. marcos_meiado@yahoo.com.br

${ }^{2}$ Universidade Federal de São Carlos, Campus Sorocaba, Bairro do Itinga, 18053-780 Sorocaba-SP, Brazil. eliana.simabukuro@gmail.com

${ }_{3}^{3}$ Departamento de Zoologia, Universidade Federal de Pernambuco, Cidade Universitária, 50670-901 Recife-PE, Brazil. iannuzzi@ufpe.br
\end{abstract}

\begin{abstract}
Entomofauna associated to fruits and seeds of two species of Enterolobium Mart. (Leguminosae): Harm or benefit? The aims of the present study were to identify the entomofauna associated to the fruits and seeds of Enterolobium contortisiliquum (Vell.) Morong and Enterolobium timbouva Mart. (Leguminosae), as well as to determine relationships among insects and the possible harm and/or benefit stemming from these associations. Fruit infestation was evaluated and the insects were identified. Seed consumption (\%) and the germination of predated seeds (\%) were determined. The fruits of E. contortisiliquum exhibited a high percentage of infestation (91\%). The most representative species in the fruits were Lophopoeum timbouvae Lameere, 1884, Merobruchus bicoloripes (Pic, 1930) and Stator limbatus (Horn, 1873). In the fruits of E. timbouva, only one species was found (S. limbatus). E. contortisiliquum seed consumption was proportionately higher $(55.2 \%)$ to that of $E$. timbouva (15\%). The germination of predated seeds from E. contortisiliquum was null, whereas $40 \%$ of predated seeds from E. timbouva germinated.
\end{abstract}

KEYWORDS. Bruchinae; Cerambycidae; Coleoptera; insect-plant interactions; seed predation.

Insects have numerous positive interactions with plants. They disperse fruit, pollinate flowers and protect plants from herbivores (Bronstein \& Barbosa 2002). However, some groups of insects, such as Coleoptera, Hymenoptera, Diptera, Lepidoptera and Thysanoptera, are seed predators and the harm these organisms cause often decreases the success of seed germination in different ecosystems (Link \& Costa 1995; Zhang et al. 1997). Most insects are considered generalists and the seeds of many plant species are attacked by a diversity of insects. However, some plants have only one species of seed predator (Zhang et al. 1997) and this interaction may benefit the plants by breaking the dormancy of seeds that have a hard coat (Takakura 2002).

Seed predation occurs in both the pre-dispersal and postdispersal periods (Zhang et al. 1997). Thus, fruit and seeds from the same plant can serve as food sources for different animals both before and after seed dispersal (Johnson \& Romero 2004). Predation in the pre-dispersal period is commonly associated to mortality of seeds that do not complete their development stages (Zhang et al. 1997). Moreover, after dispersal, some insects consume seeds on the soil surface or buried seeds that form the soil seed bank. Thus, both predispersal and post-dispersal seed predation increase seed mortality rates (Hulme \& Borelli 1999).

Most pre- and post-dispersal seed predators belong to the Insecta and beetles of the subfamily Bruchinae (Coleoptera, Chrysomelidae) have the highest number of species associated to fruits and seeds (Johnson \& Romero 2004). Bruchine larvae feed and live in the seeds of about 35 families of plants, with about $85 \%$ of the host records in Leguminosae, whereas $4 \%$ are in Arecaceae, 4\% in Convolvulaceae and 2\% in Malvaceae (Johnson 1981; Johnson \& Romero 2004). The remaining $5 \%$ are in other families of host plants (Johnson 1981). Bruchine beetles require only one seed to complete development and the choice for the largest seeds is related to the amount of resources necessary to the survival of the insect (Janzen 1969). Thus, the production of small seeds may be a plant adaptation to reduce seed predation and ensure the success of seedling establishment (Lomônaco 1994; Harms \& Dalling 2000).

The aims of the present study were to identify the entomofauna associated to the fruits and seeds of two species of Enterolobium Mart. (Leguminosae) that have seeds with different sizes [Enterolobium contortisiliquum (Vell.) Morong and Enterolobium timbouva Mart.] and to determine the relationships among insects and the possible harm and/or benefit stemming from these associations. Specifically, it was evaluated (1) fruit infestation; (2) the percentage of seeds in different categories; (3) the abundance and richness of insects; (4) their emergence from the host fruit and (5) the consumption and (6) germination of predated seeds.

\section{MATERIAL AND METHODS}

The present study was conducted with fruits from two leguminous species collected in the state of Pernambuco, in northeastern Brazil. According to Queiroz (2009), Enterolobium is a strictly Neotropical genus composed of 10 species 
with continuous distribution from Central to South America. In Brazil, most species occur in nearly all states and grow as trees more than $20 \mathrm{~m}$ high (Queiroz 2009). Fruits from $E$. contortisiliquum, which is locally called "orelha-de-nego", were collected from 10 adult plants growing in the municipality of Pesqueira ( $08^{\circ} 20^{\prime} \mathrm{S}, 36^{\circ} 46^{\prime} \mathrm{W}$; altitude: $1050 \mathrm{~m}$ ), which has an average annual temperature and rainfall of $22.4^{\circ} \mathrm{C}$ and $662 \mathrm{~mm}$, respectively (LAMEPE/ITEP 2010). Fruits from E. timbouva, locally known as "timbaúva", were collected from 10 trees growing in the municipality of Alagoinha ( $08^{\circ} 27^{\prime} \mathrm{S}, 36^{\circ} 46^{\prime} \mathrm{W}$; altitude: $\left.762 \mathrm{~m}\right)$, which has an average annual temperature and rainfall of $21.6^{\circ} \mathrm{C}$ and $597 \mathrm{~mm}$, respectively (LAMEPE/ITEP 2010).

Fruit infestation and seed categories. In the period of fruit production (last quarter of the year), 200 fruits were collected from each leguminous species per year from 2002 to 2004. For the assessment of fruit infestation (\%), 300 fruits from each species, collected over the three-year period $(\mathrm{n}=$ 100 fruits per year), were randomly chosen for signs of predation (insect emergence aperture) on fruits and seeds. Moreover, the seeds were classified into four categories: intact seed, aborted seed, predated seed and seed contaminated by fungi. Intact seeds were those with normal development (nonaborted seed) and no injuries caused by microorganisms. Predated seeds were those with an emergence aperture, indicating the presence of larvae, pupae or adult insects inside (Lomônaco 1994). The chi-square test was used for the comparison of the percentage of intact fruits versus infested fruits for each species. Two-way analysis of variance (ANOVA; category and year) with Tukey's a posteriori test was used to compare seed categories for both species over the three-year period.

Entomofauna identification and insect emergence. The entomofauna present in the fruit and seeds of both species collected in 2004 were identified and immediately isolated in plastic bags $(25 \times 15 \mathrm{~cm})$ upon collection. Fruits were opened at 10-day intervals (10 fruits, 10 times, and totaling 100 fruits from each species) for the identification of the entomological groups inside and the observation of insect instars. All analyses were performed under ambient conditions. The number of emergence apertures in each infested fruit and seed were recorded. Insects were initially identified at the family level and species identification was performed by Dr. Renato $\mathrm{C}$. Marinoni and Dr. Norma G. Ganho (Cerambycidae), Dr. Cibele S. Ribeiro-Costa (Chrysomelidae), Dr. Inara R. Leal (Formicidae), Dr. Ayres Menezes Junior (Braconidae). All specimens were incorporated to the Coleção Entomológica da Universidade Federal de Pernambuco (CE - UFPE), Brazil. Following the identification of the species, the abundance and richness of the insects were recorded.

One hundred fruits from each species (also collected in 2004) were used for the observation of insect emergence from the hosts. These fruits were divided into 10 samples and kept in boxes with lids. The emergence of adults at 7-day intervals over a 12 -month period was observed. All fruits were then opened to determine the occurrence of insects.
Consumption and germination of predated seeds. To evaluate the consumption of resources necessary to complete the larval stage, both predated and intact seeds $(n=100$ seeds from each seed category, divided into 10 samples) were used. The seeds were weighed using an analytical scale (HR200, A\&D Company Limited, Japan) and kept in incubators (Incubator $315 \mathrm{SE}$, FANEM, Brazil) at $103^{\circ} \mathrm{C}$ until complete dehydration (Brasil 2009). The seeds were then re-weighed and the dry biomass values were recorded. Insect consumption (\%) was determined by the difference in biomass between intact and predated seeds (Santos et al. 1994).

Seeds were sowed in trays containing soil as substrate (100 predated seeds from each species placed in 5 trays) to evaluate the germination of predated seeds. The trays were kept in a greenhouse for a 60-day period with daily water supply. Intact seeds (chemically scarified by 30-minute immersion in sulfuric acid) were used as control. Seedling emergence was the criterion for germinated seeds. Germination was daily recorded and the data from each species were arcsine transformed and compared by using the Student's t-test (Ranal \& Santana 2006).

Data were expressed as mean \pm standard deviation (SD) values. The Shapiro-Wilk and Levene tests were used to test for normal distribution of the data and homogeneity of the variances, respectively. All statistical analyses previously described were carried out using the STATISTICA 7.0 program, with the level of significance set at 0.05 (Zar 1999).

\section{RESULTS}

Fruit infestation and seed categories. In E. contortisiliquum, there were significantly more infested fruits than intact fruits $\left(2002: \chi^{2}=81.0, \mathrm{df}=1, \mathrm{p}<0.0001,2003: \chi^{2}=\right.$ 51.8, df $\left.=1, \mathrm{p}<0.0001,2004: \chi^{2}=64.0, \mathrm{df}=1, \mathrm{p}<0.0001\right)$, whereas there was a low percentage of infestation in the fruits and seeds of $E$. timbouva $\left(2002: \chi^{2}=77.4, \mathrm{df}=1, \mathrm{p}<0.0001\right.$, 2003: $\chi^{2}=73.9, \mathrm{df}=1, \mathrm{p}<0.0001,2004: \chi^{2}=57.8, \mathrm{df}=1$, $\mathrm{p}<0.0001$, Fig. 1). The same fruit infestation pattern occurred throughout the three years of the study.
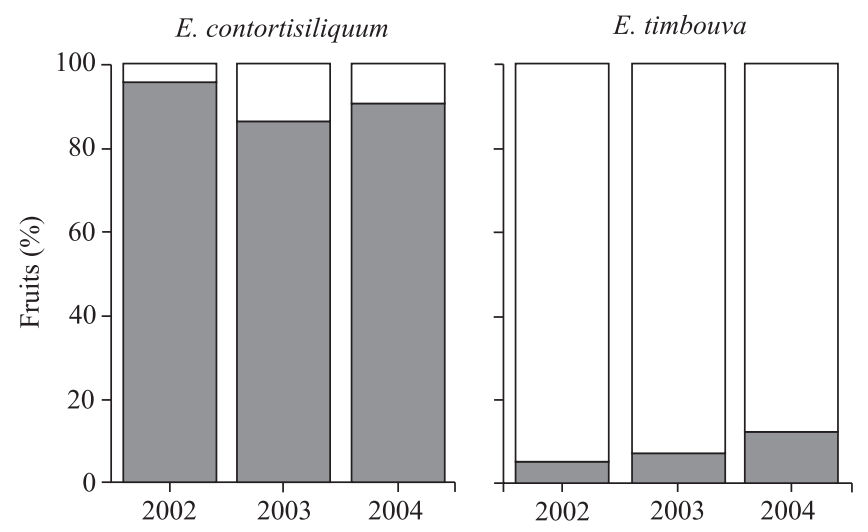

Fig. 1. Fruit infestation (\%) of two species of Enterolobium Mart. (Leguminosae) collected in the state of Pernambuco, in northeastern Brazil, from 2002 to 2004. ( $\square$ ) Intact fruits, ( $\square$ ) infested fruits. 
The same pattern was found in the seed categories for both species (E. contortisiliquum: $\mathrm{F}=3.541, \mathrm{df}=3, \mathrm{p}=0.0743 ; E$. timbouva: $\mathrm{F}=9.463, \mathrm{df}=3, \mathrm{p}=0.2539)$. However, significant differences were found among seed categories for each species (E. contortisiliquum: $\mathrm{F}=8.771, \mathrm{df}=3, \mathrm{p}=0.0122 ; E$. timbouva: $\mathrm{F}=12.128, \mathrm{df}=3, \mathrm{p}=0.0021)$. A high percentage of intact seeds were found in the fruit of both species (Figs. 2A, 2B). There were also a high percentage of predated seeds from E. contortisiliquum (Fig. 2A) and aborted seeds from $E$. timbouva (Fig. 2B). Furthermore, E. contortisiliquum seeds were more contaminated by fungi (Fig. 2A).

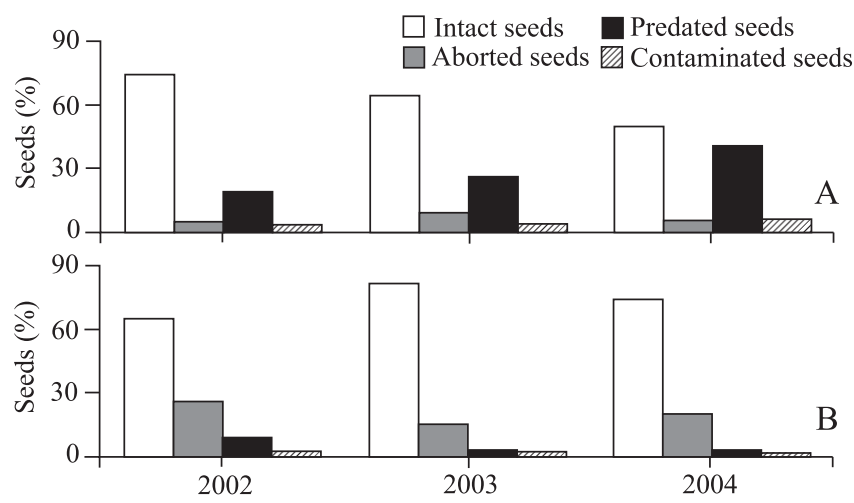

Fig. 2. Seed categories (\%) of two species of Enterolobium Mart. (Leguminosae) collected in the state of Pernambuco, in northeastern Brazil, from 2002 to 2004. (A) Enterolobium contortisiliquum (Vell.) Morong and (B) Enterolobium timbouva Mart.

Entomofauna identification and insect emergence. A total of 175 specimens of Insecta associated to the fruit of Enterolobium were found. The abundance and species richness of insects found in the fruit and seeds of E. contortisiliquum were significantly higher than those found in E. timbouva (Table I). Insects from four different orders were found in the fruits of the former species and only a single species of insect in the fruits and seeds of the latter species (Table I). In fruits from E. contortisiliquum, 159 insects in different stages of development were found $\left(1.59 \pm 2.16\right.$ insect.fruit $\left.^{-1}\right)$, belong- ing to the orders Coleoptera (123 specimens), Hemiptera (1 specimen), Hymenoptera (31 specimens) and Lepidoptera (4 specimens). Among the beetles, two families were very frequent: Cerambycidae and Chrysomelidae (Table I). In fruits from $E$. timbouva, only 16 specimens were found $(0.16 \pm 0.09$ insect.fruit ${ }^{-1}$ ), all from the same order (Coleoptera).

The insect with the greatest frequency of occurrence in the fruits from E. contortisiliquum was Lophopoeum timbouvae Lameere, 1884 (Coleoptera, Cerambycidae, Lamiinae). This species accounted for $57.9 \%$ of the insects found in the fruits and occurring in $56 \%$ of the fruits, with representatives from the different development stages (larva, pupa and adult). The subfamily Bruchinae was represented by the occurrence of two species-Merobruchus bicoloripes (Pic, 1930) and Stator limbatus (Horn, 1873) - the former species being found in all infested fruits from E. contortisiliquum. All emergence apertures in the fruits of E. contortisiliquum were related to the species $M$. bicoloripes. In $35 \%$ of the fruits, representatives of $M$. bicoloripes were still found in the pupal chamber. Moreover, $2.4 \pm 1.5$ emergence apertures were found per infested fruit (mean \pm standard deviation), ranging from a minimum of zero (intact fruit) to a maximum of eight apertures, indicating the presence of up to eight individuals of $M$. bicoloripes feeding on the seeds of a single fruit. On the other hand, the oviposition of $S$. limbatus occurred directly on the seeds, all of which exhibited emergence apertures made by this species, with a mean of $5.2 \pm 1.9$ apertures per seed in the seeds of $E$. contortsiliquum ( $\mathrm{n}=5$ seeds) and $8.9 \pm 2.1$ in the seeds of E. timbouva $(\mathrm{n}=20)$. All individuals of $S$. limbatus were found either within the seeds or leaving the seeds immediately after being removed from the fruits. These individuals were found in 2 and $12 \%$ of the fruits from E. contortisiliquum and E. timbouva collected in 2004, respectively.

Wasps from the genus Heterospilus Halliday (Hymenoptera, Braconidae, Doryctinae) were found in $40 \%$ of the fruits from E. contortisiliquum. Together with ants, they made Hymenoptera the order with the second greatest frequency of occurrence in the fruits. In all fruits in which the occurrence of Heterospilus sp. wasps was observed, representatives of the cerambycid L. timbouvae were found in the larval stage and emergence apertures of the bruchid $M$.

Table I. Abundance and percentage of insects found within fruits of two species of Enterolobium Mart. (Leguminosae) collected in the state of Pernambuco, in northeastern Brazil, from 2002 to 2004.

\begin{tabular}{|c|c|c|c|c|c|c|}
\hline & \multirow{2}{*}{ Taxa } & & \multicolumn{2}{|c|}{ E. contortisiliquum } & \multicolumn{2}{|c|}{ E. timbouva } \\
\hline & & & Abundance & $\%$ & Abundance & $\%$ \\
\hline \multirow[t]{5}{*}{ Coleoptera } & Anobiidae & Unidentified species & 5 & 3.14 & - & - \\
\hline & Chrysomelidae & Merobruchus bicoloripes (Pic, 1930) & 11 & 6.92 & - & - \\
\hline & & Stator limbatus (Horn, 1873) & 5 & 3.14 & 16 & 100.00 \\
\hline & Cerambycidae & Lophopoeum timbouvae Lameere, 1884 & 92 & 57.86 & - & - \\
\hline & Cucujidae & Unidentified species & 10 & 6.29 & - & - \\
\hline \multirow[t]{2}{*}{ Hymenoptera } & Braconidae & Heterospilus sp. & 27 & 16.98 & - & - \\
\hline & Formicidae & Tapinoma melanocephalum (Fabricius, 1793) & 4 & 2.52 & - & - \\
\hline Hemiptera & - & Unidentified species & 1 & 0.63 & - & - \\
\hline Lepidoptera & - & Unidentified species & 4 & 2.52 & - & - \\
\hline
\end{tabular}


bicoloripes were also found in these fruits. No wasps were found in intact fruits, even those with larvae of the cerambycid in their interior. Among the Dolichoderinae (Formicidae), individuals of Tapinoma melanocephalum (Fabricius, 1793) were also found in the fruits from E. contortisiliquum that exhibited emergence apertures made by the species $M$. bicoloripes (Table I).

No emergence of any insect was observed in the fruits from E. timbouva during the 12 months of observation. After this period, the fruits were opened, revealing an absence of insects within them. On the other hand, three species of insects emerged from the fruits of E. contortisiliquum that were under analysis: L. timbouvae, M. bicoloripes and S. limbatus, at a proportion of 1:0.5:0.1, respectively. The insects began to emerge on the first day of the experiment and their emergence was accompanied throughout the third month of observation. After 12 months, the fruits were opened and, in the interior of intact fruits (with no emergence apertures), there was only the presence of live adults of the species L. timbouvae ( $\mathrm{n}=27$ individuals), which did not emerge during the observation period.

Consumption and germination of predated seeds. $E$. contortisiliquum seed consumption by insects accounted for more than the half seed biomass. This high consumption is mainly related to the consumption on the part of bruchids (M. bicoloripes). The low biomass of consumed seeds from E. timbouva was due to the occurrence of only one small bruchid (S. limbatus) (Table II).

Table II. Seed biomass (g), consumption (\%) and germinability (\%) of intact and predated seeds of two species of Enterolobium Mart. (Leguminosae) collected in the state of Pernambuco, in northeastern Brazil, from 2002 to 2004 . Data is expressed as mean \pm standard deviation.

\begin{tabular}{cccc}
\hline \multicolumn{1}{c}{ Species } & $\begin{array}{c}\text { Seed biomass } \\
(\mathrm{g})\end{array}$ & $\begin{array}{c}\text { Consumption } \\
(\%)\end{array}$ & $\begin{array}{c}\text { Germinability } \\
(\%)\end{array}$ \\
\hline E. contortisiliquum & & & \\
$\quad$ Intact seed & $2.75 \pm 0.24$ & - & $98.0 \pm 4.2$ \\
$\quad$ Predated seed & $1.23 \pm 0.18$ & $55.2 \pm 4.9$ & $0.0 \pm 0.0$ \\
E. timbouva & & & \\
$\quad$ Intact seed & $8.78 \pm 0.54$ & - & $95.0 \pm 5.3$ \\
Predated seed & $7.46 \pm 0.32$ & $15.0 \pm 3.6$ & $40.0 \pm 6.7$ \\
\hline
\end{tabular}

The germination of predated seeds from E. contortisiliquum was null. On the other hand, predated seeds from E. timbouva (the consumption of which was proportionately lower) germinated and formed normal seedlings, although germination was significantly reduced $(\mathrm{t}=2.675, \mathrm{df}=8, \mathrm{p}=0.0329$, Table II). The predated seeds that germinated did not need any pre-germination treatment for breaking dormancy due to the insect emergence aperture.

\section{DISCUSSION}

Most insects found in the present study belonged to Chrysomeloidea and species from this superfamily diverge in relation to food habits (Marinoni et al. 2001). Cerambycidae find different niches during their development, but most species complete development by forming galleries within the stem of woody plants (Marinoni et al. 2001). Insects from Chrysomelidae use different parts of plants as food sources, such as leaves, stems, roots and flowers (Marinoni et al. 2001). Moreover, the development of bruchine beetles (Chrysomelidae, Bruchinae) is associated with seeds from angiosperms (Johnson \& Romero 2004).

In the present study, L. timbouvae had the highest frequency of occurrence. Specimens of this species were found even within intact fruits, with no emergence aperture on the exocarp to indicate their presence within. This cerambycid forms galleries and feeds on the mesocarp; the consumption of this organ is different than that expected for the ecological niche of Cerambycidae. Intact fruits with L. timbouvae in different stages of development ( $40 \%$ of intact fruits) had seeds with no signs of consumption by the insect, which suggests that this species does not use seeds as a food source. Furthermore, galleries were observed along the margin of the fruit and the mesocarp was completely consumed when more than three insects inside the fruit were encountered. According to Di Iorio (1995), these cerambycids are commonly found in the fruits of E. contortisiliquum and their larvae can partially or completely devour seeds (Santos et al. 1994; Di Iorio 1995). However, consumption is proportionately low (2.26\%) when compared to all predated seeds (Santos et al. 1994). Link \& Costa (1995) state that the larvae from this species feed on and damage the seeds as well as other bruchine larvae that live within the fruit. Thus, seed consumption by these larvae may be related to the density of individuals within the same fruit as well as to the availability of food sources for these insects.

In addition to insects from Cerambycidae, bruchine beetles were also frequent in fruits of Enterolobium. According to Johnson \& Romero (2004), there are three oviposition guilds of Bruchinae that feed on seeds from Leguminosae and two of these guilds were found in the present study. Some species lay eggs on fruits while they are attached to the parental plant (as observed in M. bicoloripes). However, there are species that only oviposit on seeds exposed in dehiscent fruits while still on the plant (as observed in $S$. limbatus), whereas other species only oviposit on seeds exposed on the substrate (Johnson \& Romero 2004).

In this study the life cycle of $M$. bicoloripes were followed and females were observed ovipositing on the fruit surface. After the development period, the larva hatches from the egg and starts looking for the resource to complete its life cycle. As observed in the present study, seed consumption accounted for more than $50 \%$ of the seed biomass and strongly impeded the germination of predated seeds. Upon completing its development, the adult individual emerges from the fruit through the same aperture used by the larva for entering, leaving it open and allowing the entrance of other individuals that interact with the seeds and other insects in the fruits.

Unlike the bruchine $M$. bicoloripes, which feeds largely on the reserve of the seed, including its embryo, the bruchine $S$. limbatus is a small insect (approximately $1.5 \mathrm{~mm}$; Morse \& 
Farrell 2005) and, as seen in the present study, consumes a very small amount of the seed. Thus, the occurrence of this insect may be beneficial to the plant, as the predated seeds, which previously exhibited tegument dormancy, were able to germinate after being partially consumed by the insect. The occurrence of bruchine beetles from this genus in the interior of fruits of Enterolobium has also been reported by Johnson (1982) and Siemens \& Johnson (1996) in the species Enterolobium cyclocarpum (Jacq.) Griseb. Individuals from the species Stator generalis Johnson \& Kingsolver, 1976 have been observed in oviposition guilds related to the egg laying in the tegument of the seeds (Johnson 1982; Siemens \& Johnson 1996), which is similar to that found in the fruits from E. contortisiliquum and E. timbouva. According to the authors, the number of seeds in an ecosystem may affect the oviposition of this species and the number of eggs found on each seed. Moreover, a greater number of eggs on the seeds may cause a loss of viability (Johnson 1982; Siemens \& Johnson 1996). Thus, the benefit offered by the species $S$. limbatus (overcoming of tegument dormancy of seeds from Enterolobium spp.) should be interpreted with caution, as the present study demonstrated that the final percentage of germination of the legume studied was significantly reduced due to consumption by this bruchine beetle.

Along with representatives from the order Coleoptera, wasps from the family Braconidae were well represented in the samples of fruits from E. contortisiliquum. As seen during the analyses, L. timbouvae were found in all fruits in which the wasps occurred. This association suggests a relationship of parasitoidism, in which the wasps oviposit on the larvae of the cerambycid. Five larvae of $L$. timbouvae were found in decomposition with wasp larvae within them. Moreover, the interaction between these insects was provided by the bruchine $M$. bicoloripes, which made possible the access to the larvae of the cerambycid upon opening the emergence aperture made by its own larvae. The relationship of parasitoidism may be favorable to the plant, as an increased percentage of cerambycid larvae attacked by wasps may reduce seed predation.

In conclusion, the results of the present study demonstrate that species from the same plant genus have different fruit infestation patterns. Moreover, the presence of some insects in the fruit was associated with the previous occurrence of other species that consume fruits while they are attached to the parental plant. Thus, the entrance of these species is linked to the occurrence of insects that have the ability to penetrate the exocarp, which allows the interaction of other species and consequent harm and/or benefit caused by these insects.

\section{ACKNOWLEDGMENTS}

The authors are grateful to the late Dr. Renato C. Marinoni (UFPR), Dr. Norma G. Ganho (UFPR), Dr. Cibele S. RibeiroCosta (UFPR), Dr. Inara R. Leal (UFPE) and Dr. Ayres Menezes Junior (UEL) for the identification of the insects; Dr. Laís A. Borges (UFPB), Dr. Mellissa S. Sobrinho (UFPE), Dr. Virág Venekey (UFPA) and M.Sc. Laura C. Leal (UFPE) for the reading of the manuscript and suggestions.

\section{REFERENCES}

Brasil. 2009. Regras para análise de sementes. Brasília, Ministério da Agricultura, Pecuária e Abastecimento, 395 p.

Bronstein, J.L. \& Barbosa, P. 2002. Multitrophic/multispecies mutualistic interactions: the role of non-mutualists in shaping and mediating mutualisms, p. 44-66. In: Tscharntke, T. \& Hawkins, B.A. (eds.). Multitrophic level interactions. Edinburgh, Cambridge University Press, 286 p.

Di Iorio, O.R. 1995. Lophopoeum timbouvae Lameere, 1884 and L. bruchi Monné \& Martins, 1976 (Coleoptera: Cerambycidae: Lamiinae: Acanthocinini): their relation to fruits of Leguminosae. Giornale Italiano di Entomologia 7: 231-245.

Harms, K.E. \& Dalling, J.W. 2000. A bruchid beetle and a viable seedling from a single diaspore of Attalea butyracea. Journal of Tropical Ecology 16: 319-325.

Hulme, P.E. \& Borelli, T. 1999. Variability in post-dispersal seed predation in deciduous woodland: relative importance of location, seed species, burial and density. Plant Ecology 145: 149-156.

Janzen, D.H. 1969. Seed-eaters versus seed size, number, toxicity, and dispersal. Evolution 23: 1-27.

Johnson, C.D. 1981. Seed beetle host specificity and the systematics of Leguminosae, p. 995-1027. In: Polhill, R.M. \& Raven, P.H. (eds.). Advances in Legume Systematics. Kew, Royal Botanic Garden, 1050 p.

Johnson, C.D. 1982. Survival of Stator generalis (Coleoptera: Bruchidae) in host seeds from outside its geographical range. Journal of the Kansas Entomological Society 55: 718-724.

Johnson, C.D. \& Romero, J. 2004. A review of evolution of oviposition guilds in the Bruchidae (Coleoptera). Revista Brasileira de Entomologia 48: 401-408.

LAMEPE/ITEP. 2010. Climatologia. Laboratório de Meteorologia de Pernambuco. Available at: http://www.itep.br/lamepe.asp (accessed 14 January 2010).

Link, D. \& E. Costa, C. 1995. Danos causados por insetos em sementes de timbaúva, Enterolobium contortisiliquum (Vell.) Morong. Ciência Florestal 5: 113-122.

Lomônaco, C. 1994. Predação de sementes de leguminosas por bruquídeos (Insecta: Coleoptera) na Serra dos Carajás, Pará, Brasil. Acta Botanica Brasilica 8: $121-127$.

Marinoni, R.C., Ganho, N.G., Monné, M.L. \& Mermudes, J.R.M. 2001. Hábitos alimentares em Coleoptera (Insecta). Ribeirão Preto, Holos Editora, $63 \mathrm{p}$.

Morse, G.E. \& Farrell, B.D. 2005. Ecological and evolutionary diversification of the seed beetle genus Stator (Coleoptera: Chrysomelidae: Bruchinae). Evolution 59: 1315-1333.

Queiroz, L.P. 2009. Leguminosas da Caatinga. Feira de Santana, Universidade Estadual de Feira de Santana, 913 p.

Ranal, M.A. \& Santana, D.O. 2006. How and why to measure the germination process? Revista Brasileira de Botânica 29: 1-11.

Santos, G.P., Anjos, N., Zanuncio, J.C. \& Alves, J.B. 1994. Danos por Caryedes bicoloripes (Pic) (Coleoptera; Bruchidae) e Lophopoeum timbouvae Lameere (Coleoptera; Cerambycidae) em frutificações de tamboril, Enterolobium contortisiliquum (Leguminosae). Revista Ciência \& Prática 18: 104-108.

Siemens, D. H. \& Johnson, C. D. 1996. Bruchid oviposition patterns beneath guanacaste trees (Mimosaceae) in Venezuela: probable consequences of extinct seed dispersers. Biotropica 28: 96-104.

Takakura, K. 2002. The specialist seed predator Bruchidius dorsalis (Coleoptera: Bruchidae) plays a crucial role in the seed germination of its host plant, Gleditsia japonica (Leguminosae). Functional Ecology 16: 252-257.

Zar, J.H. 1999. Biostatistical analysis. New York, Prentice Hall Inc., 929 p.

Zhang, J., Drummond, F.A., Liebman, M. \& Hartker, A. 1997. Insect predation of seeds and plant population dynamics. Technical Bulletin 163. Orono, University of Maine, $32 \mathrm{p}$.

Received 15 October 2012; 21 December 2012

Associate Editor: Paulo Roberto V. S. Pereira 